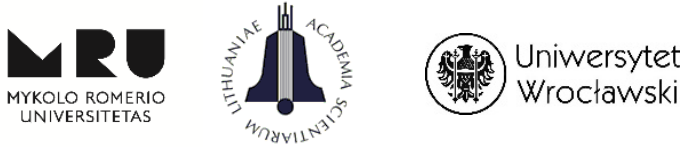

\title{
PURCHASING POWER AND VALUE OF THE AVERAGE WAGE IN THE BALTIC STATES
}

\author{
Rimvydas JASINAVIČIUS \\ Mykolas Romeris University \\ E-mail: rimjas@mail.lt \\ Vidmantas GANIPRAUSKAS \\ Mykolas Romeris University \\ E-mail: vidgan@mruni.eu \\ doi:10.13165/IE-14-8-2-03
}

\begin{abstract}
Before the financial crisis, the Baltic States had the highest growth rate of the Gross domestic product (hereinafter - GDP) in the European Union. Also, these States were called "the Baltic tigers". During the crisis, the decline of GDP was the highest in the Baltic States. After the crisis, economic indicators of Estonia economy had the highest growth rates in the European Union. Such progress and life quality in Estonia surprises the other two neighboring Baltic States - Latvia and Lithuania. However, GDP of Lithuania exceeds the GDP indicator of Estonia almost twice in absolute value (Eurostat). Since October 1, 2014, the minimum monthly wage in Lithuania increased by 3.5 percent. Based on information provided by the European Union Statistics (hereinafter - Eurostat), from 2004, the average wage in the Baltic States on average increased by 8.2, 10.3, and 7.7 percent per annum. It should be emphasized that the growth rate of the average wage in monetary expression significantly fell behind the actual decline rate of the wage purchasing power. During the period of 2004-2013, the purchasing power and value of the average wage in the Baltic States has decreased in respectively assessing by the standard coefficient of inflation and the "Gold Standard”.
\end{abstract}

JEL classification: E31, E24. 
Keywords: the value of income and depreciation, the value of income calculation, the value of the average monthly wages, the effect of inflation.

\section{Introduction}

It is generally acknowledged that income is the main factor determining the quality of life. Income is comprised of wages and subsidies from social funds. Both of these sources of income depend on the general state economic results and the level of payment for work. The general state economic results are most often judged by the GDP (gross domestic product) rate, and the labour income - by the national average wage. In each country, both of these rates and their changes are evaluated (calculated) according to the value of the nominal amount of money used in that country, regardless of the changes in the value of money and in the purchasing power.

According to the statistical data of the Baltic States, the average wage and GDP increased each year in Estonia, Latvia and Lithuania (hereinafter referred to as Baltic States) during the period of 2004-2013. These facts promote an assumption that the quality of life of people in these countries has also improved accordingly. However, a large part of the population of these countries argues the contrary - purportedly, their quality of life did not improve, and often even became worse.

Economic experts examine the factual or relative changes in wages, calculated through quantitative values of the national currency (Žukauskas, 2008; Raškinis, 2005). There are publications and research revealing the impact of inflation on the purchasing power of personal income (Žukauskas, 2011, Jasinavičius, Ganiprauskas 2014). However, the scientific literature does not sufficiently analyse the proportions in which changes occur in the personal income value when the average monthly wage varies in the Baltic States. When analysing the period of 2004-2013, since 2004 and according to the numerical value, annually, the average wages in Estonia, Latvia and Lithuania have increased accordingly on an average of 8.2; 10.3 and 7.7 percent per year. However, many believe that these growth rates did not ensure the proportional increase of its purchasing power.

This research is limited to the analysis of the changes in the average wage value in the Baltic States over the last decade and the purchasing power, in terms of the "Gold standard" and taking into account the standard inflation coefficient variation.

From 1 October 2014, the minimum monthly wage in Lithuania has increased to 300 EUR. It is estimated that wage is the main motivating factor for employees and, when prices of personal consumption goods and services rise, employees usually expect for their wages to grow according to the increase in the price level (Žiogelytè, 2010).

The aim of the research: to quantify changes in the average wage value and the purchasing power taking into account not only the increase in the average wage, but also the partial devaluation of money used in the countries and the correlations of these changes with the main economic indicators in the Baltic States. 


\section{Research objectives:}

1. to reveal the computational characteristics of changes in the value of income;

2. to assess the losses of the average monthly wage due to price inflation and devaluation;

3. to determine the correlation of the average wage with the main economic indicators.

When analysing the scientific literature published in the period of 2004-2013, it was found that L. and T. Tanning have analysed wage rates, labour costs and productivity in the Eastern Europe and the Baltic States (Tanning, 2012 and 2013), L. Žiogelytè has assessed the wage increase in the Lithuanian labour market (Žiogelytė, 2010), E. Paužinskaite has examined the peculiarities of the population income taxation in the Baltic States (Paužinskaitè, 2012), V. Gerikienè and I. Blažienè have analysed the regulation of labour payment of public sector employees in Lithuania (Gerikienė, Blažienè, 2009), while A. Baležentis and others distinguished only a specific sector when assessing changes in wages in the Lithuanian agricultural sector during an economic downturn. (Baležentis, Misiūnas, 2011). V. Laidmäe and others assessed the successful life of elderly in Estonia (Laidmäe, Hansson, Leppik, Tulva, Lausvee, 2013). Although there are already a number of articles analysing the peculiarities of money value measuring, there is a lack of scientific articles that analyse changes in wage value. The analysis and presentation of this issue will supplement the scientific literature with scientific arguments on the earned income value reduction in the Baltic States. Since the purchasing power of people depends not only on the amount of money available, but also on their value, special attention in the research is given to the evaluation of changes in the value of income.

\section{Research on changes in the value of income}

Income is usually assessed directly according to its amount. Thus, it is considered that any increase in the amount - enhances, and decrease - diminishes the value of income. So, it would be fair if the material value of used monetary units and their purchasing power remains constant without changing over time:

here: $\quad$, - monetary unit value at a given moment $t$ and 0 .

This rule applied when people used gold and silver coins as money. In part, this rule also applied when paper money, tied to gold reserves by a Gold Standard, became the used currency: each paper banknote was assessed and could be exchanged for a specific amount of gold. This amount of gold determined the material value of available and used money, which is calculated according to formula (2): 
here $\quad$ - income value at an $i$-moment; _ - number of monetary units, obtained at a given $i$ moment; $\quad$ - monetary unit value at a given $i$ moment.

If the material value of money is calculated according to the net weight of gold, then

and become gold content, which can be acquired for existing banknotes. Such money value calculation is conditionally called the Gold Standard, meaning that the standard content of pure gold - ounce - has a particular and sustained price of money expressed in selected monetary units.

Gold ounce price variations in the market signal to changes of the value of money used for purchasing it: when gold "becomes more expensive", it can be argued that this is the outcome of devalued money. Change in the value of money in relation to the price of gold $\boldsymbol{A}_{\boldsymbol{0}}$, hereinafter referred to as monetary depreciation according to the "Gold Standard", during the analysed period $t$, can be evaluated in aspect (3):

here $\boldsymbol{F}_{\boldsymbol{A}}-$ money inflation coefficient according to the "Gold Standard", $\boldsymbol{A}_{\boldsymbol{0}}$ and $\boldsymbol{A}_{\boldsymbol{t}}$ - gold ounce prices at the initial moment 0 and the analysed moment $t$.

Income value according to the "Gold Standard"

is calculated on the basis of formula 4:

After 1971, when cancelling the correlation of reserve currency - US Dollar with the Gold Standard, the money of all States lost some of their necessary properties by becoming "Monetary signs" mainly performing turnover and payment functions in local areas during a limited period of time.

Therefore, when using them, the property of their purchasing power is put in first place. The purchasing power of money and its changes can be calculated according to the price variations of acquired valuables: plots of land, raw materials, daily consumption goods and services. The latter are used for the assessment of the purchasing power of money to determine the used standard inflation coefficient. According to the Statistics Lithuania, inflation is defined as a continuous increase of the general price level that reduces the purchasing power of money (Statistics). 
Price inflation or deflation is calculated according to the changes in prices of basic valuables, i.e. the basket of goods and services (statistical basket) concluded by Statistics, which, in Lithuania alone, consists of 902 representative goods and services. The statistical basket consists of goods and services, which represent the country's household consumption expenditure (Statistics).

\section{$\mathbf{I}_{\mathbf{N}_{\mathbf{n}}} \quad \mathbf{I}_{\mathbf{N}_{\mathbf{n}} \mathbf{n}}$ \\ $\mathbf{I}_{\mathbf{N} \boldsymbol{\Sigma} \mathbf{n} \%}=\mathbf{I}_{\mathbf{N} \boldsymbol{\Sigma}_{\mathrm{n}} \cdot 100 \%}$
$\mathbf{I}_{\mathbf{N} \boldsymbol{\Sigma} \mathbf{n} \%}=\mathbf{I}_{\mathbf{N} \boldsymbol{\Sigma}_{\mathbf{n}} \cdot 100 \%}$,

here: $\quad-$ storage inflation coefficient during the period from the base moment in time $\boldsymbol{o}$ to the next analysed moment in time $\boldsymbol{t}$.

The purchasing power of income according to the multiplicative standard inflation coefficient is calculated according to formula 6 :

In order to assess the changes in the material value of accumulated money, it is not enough to be limited to only a price inflation rate. It is necessary to determine their material value in relation to gold additionally.

Thus, these two national currency assessment characteristics were used in the research of changes in average wages in the Baltic States.

The purchasing power and value of the average monthly wage is analysed in such approaches according to the multiplicative standard inflation coefficient and the "Gold Standard", by using aspect (4). On the basis of methodology for calculating the value of income through which the devaluation rate of money is determined, the devaluation extent of the average monthly wage in the Baltic States during the period of 2004-2013 is analysed (see Figures 1 and 2), (Jasinavičius, Ganiprauskas, 2012).

According to Figure 1, the value of Euro during $\boldsymbol{p}_{v 2013}$ according to the price of gold in the market (873 EUR/ Au oz) decreased by 2.72 times since 2004. It means that in 2004, $882.8 \mathrm{~g}$ of gold could be purchased for an existing sum of $10.000 \mathrm{EUR}$, while in 2013 - only $324.9 \mathrm{~g}$. The performed calculations show that the value of 10.000 EUR income received a decade ago has decreased to -66 percent. It is an obvious devaluation of money when purchasing gold with a constant value and weight. If the material value of one Euro would not 
have changed:

, then it would have been possible to purchase the same amount of gold $-882.8 \mathrm{~g}$ for the same 10.000 EUR during the analysed period. However, it was only possible to purchase a 2.72 times smaller amount of gold for a sum of 10.000 EUR during the analysed period.

Since changes in the general price level, assessed by the country's standard inflation coefficient, were different in the Baltic States, this affected the different changes in the purchasing power of money used in these States.

Figure 1: the value of Euro according to the price of gold in the market

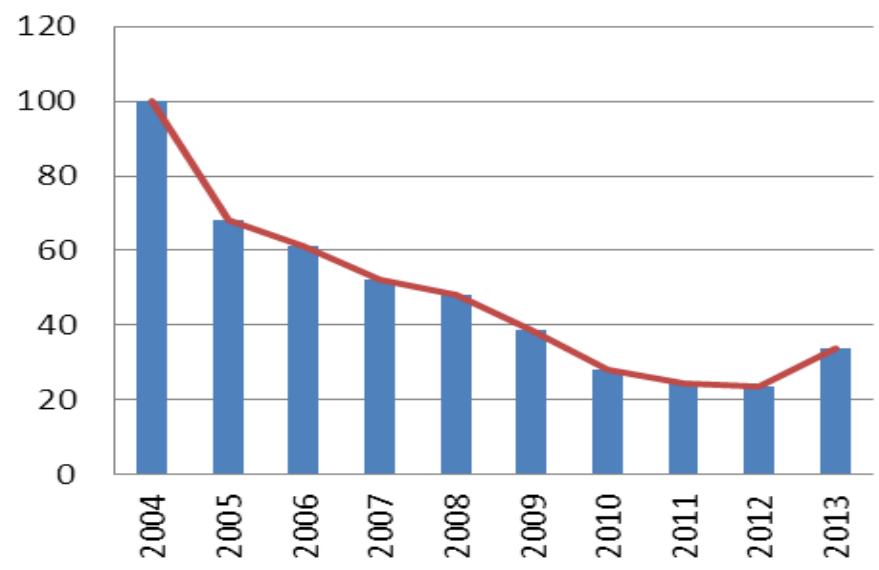

The value of Euro according the "Gold Standart"

Source: Eurostat and The London Bullion Market Association data (Author's calculations) 
Figure 2: the purchasing power of Euro in the Baltic States according to the multiplicative standard inflation coefficient

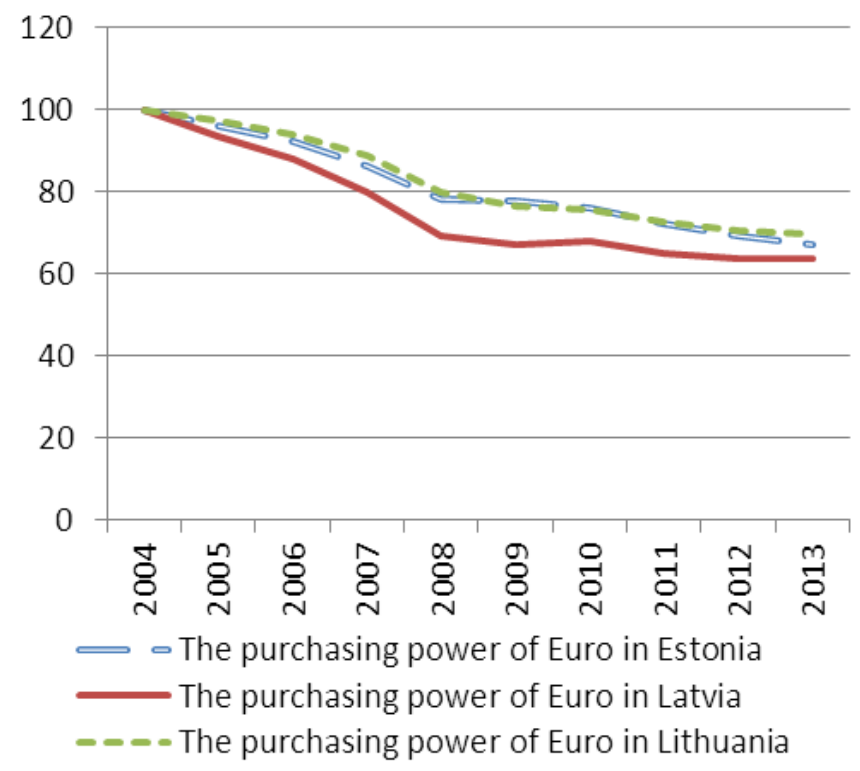

Source: Eurostat and The London Bullion Market Association data (Author’s calculations)

According to Figure 2, the purchasing power of Euro $\boldsymbol{p}_{\boldsymbol{F v 2 0 1 3}}$ in the Baltic States during 2013, according to the multiplicative standard inflation coefficient, has decreased by 1.4 times since 2004. It means that the purchasing power of 10.000 Euros accumulated since 2004 has declined to 6.961 EUR in the Baltic States.

\section{4-2013}

2. Analysis on the value of the average monthly wage in the Baltic States during

Wage is the primary source for meeting the needs of most people, and it reflects the average tendency of income earned by the country's population. During the research, the average monthly wage was analysed in the Baltic States during 2004-2013. Statistical data were used from the London Bullion Market Association and the Statistical Office of the European Union (hereinafter referred to as Eurostat).

According to Figure 3, it is noted that variations of the absolute AW in the Baltic States consist of 3 phases: 1) during the pre-crisis period in 2004-2008 AW increased on an 
average of 18.8 percent each year; 2) during the crisis in 2008-2010 AW decreased on an average of 2.2 percent each year; 3) after the crisis in 2010-2013 AW started to increase on an average of 4.5 percent each year. Meanwhile, after performing a comparative statistical analysis, the absolute AW in the Baltic States during 2004-2013 has increased by an average of 8.7 percent each year. According to the data in Figure 4, during 2013, the absolute AW values $N_{n 2013}$ in Estonia, Latvia and Lithuania increased accordingly to 900, 716 and 646 EUR/ month. During the analysed period, the relative purchasing power of the AW in these States when assessing the multiplicative impact of the standard inflation coefficient $\boldsymbol{P}_{\mathbf{v 2 0 1 3}}$ amounted accordingly to only 603, 455 and 450 EUR/ month. In 2013, the AW value, according to the "Gold Standard" and in comparison to the absolute AW, has decreased to 63 percent in the Baltic States.

Figure 3: The value of the average monthly wage, the purchasing power and their changes in the Baltic States, when accordingly assessing the "Gold Standard" and the effects of inflation
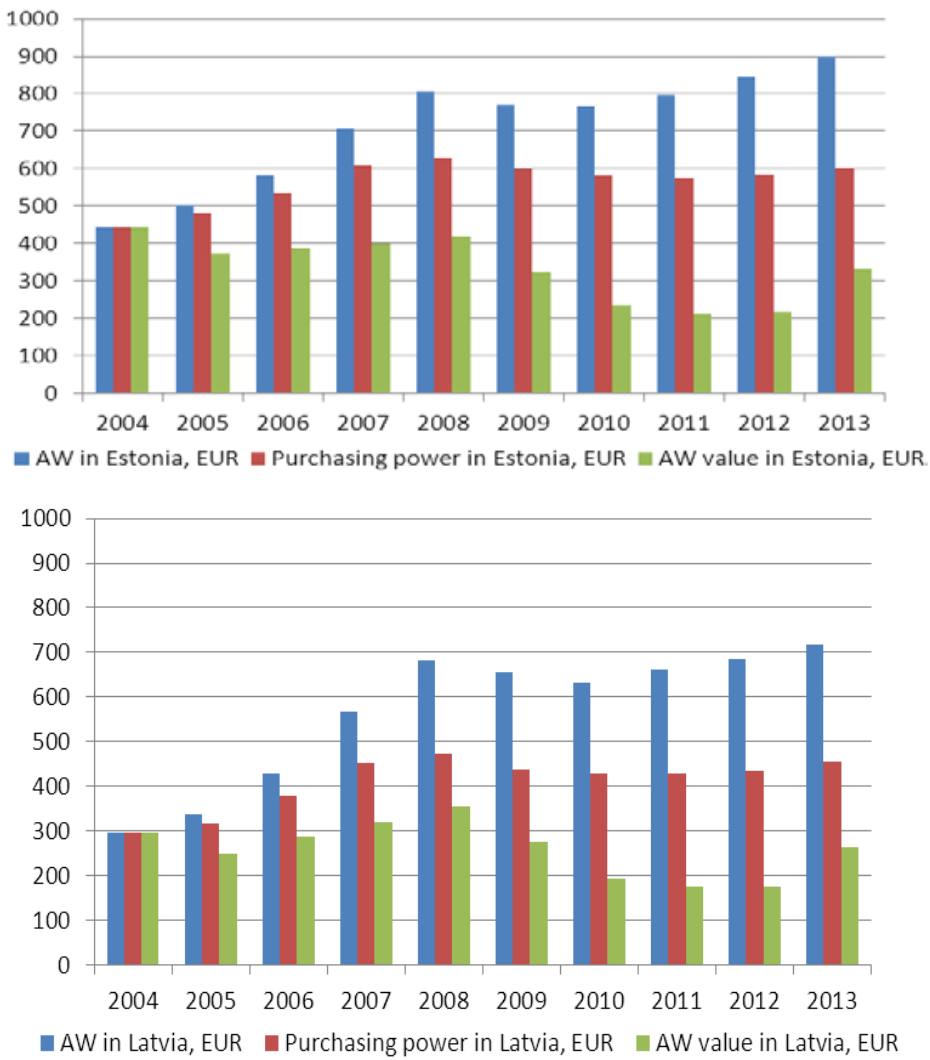


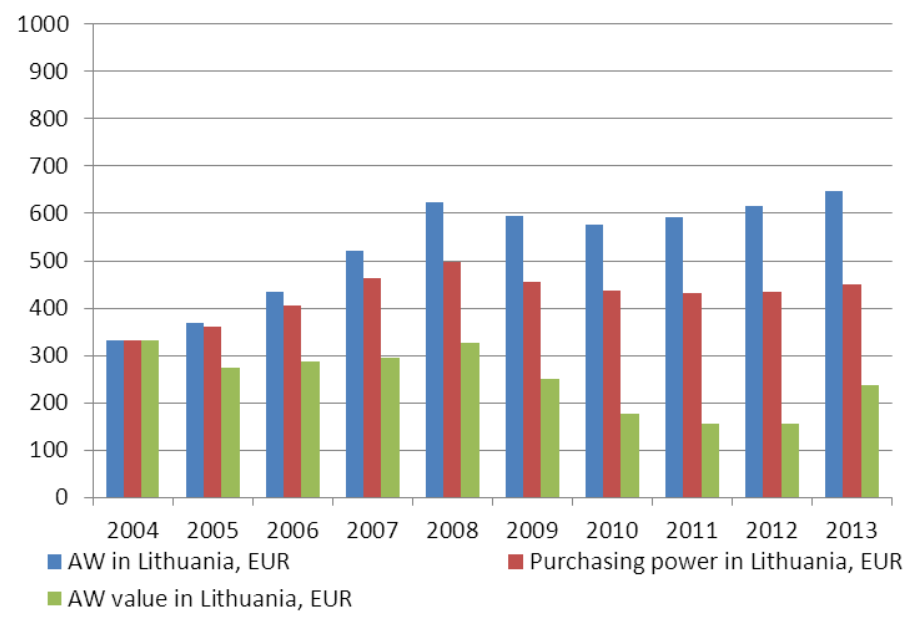

Source: Eurostat and The London Bullion Market Association data (Author's calculations)

The absolute AW value in Estonia, Latvia and Lithuania amounted accordingly to 716 and $646 \mathrm{EUR} / \mathrm{month}$, while the AW value $\boldsymbol{P}_{\text {vA2013 }}$ according to the "Gold Standard" amounted accordingly to only 331, 264 and 238 EUR/ month, when calculating according to the monetary value that occurred a decade ago. Thus, in all the Baltic States, the value of received AW decreased since 2004 while the purchasing power decreased since the beginning of the crisis in 2008. It means that you can purchase fewer goods and services than before for the actually increasing AW after the crisis period, and in the future, when the World Gold Prices increase, it will be possible to purchase even fewer goods and services for a similarly increasing AW. If the tendencies of values of the quantitative growth of AW and of the monetary unit-euro, and purchasing power variations persist, the income value and the purchasing power of the major part of the Baltic country population will decrease causing impoverishment.

The calculation results presented in Figure 3 clearly demonstrate that, despite the growth of the average wage values (blue columns) on an average of 7.7; 8.7 and 10.3 percent each year, such increase in income value does not outweigh the decrease in the purchasing power of income according to the multiplicative standard inflation coefficient (red columns), and the decrease in the income value according to the "Gold Standard" (green columns).

\section{Correlation-regression analysis of the average wage}

It is necessary to perform a correlation regression analysis in order to identify the correlations between various statistical indicators. 
Correlation describes relation strength between variables, while regression analysis enables to determine the nature of this relation and describe the average value dependence of the dependent (outcome) variable on one or a few values of independent (cause) variables according to a mathematical formula and also — predict the values of this variable. When applying the method of correlation regression analysis, an analytical aspect of regression equation is often used:

here: $y_{x}$ - independent feature aspect affecting the dependent feature;

$a_{0}$ - equation parameters, calculated by the least squares method;

$a_{1}$ - regression coefficient.

Regression coefficient $\left(a_{1}\right)$ shows how many units (its units of measurement) will the resulting variable change, when the factorial variable is increased by one unit (Weixin, Longhai, 2014). If such coefficient is negative, this means that the relation between the analysed variables is reverse, i.e. when one increases, the other decreases.

Parameters $\mathrm{a}_{0}$ and $\mathrm{a}_{1}$ can be calculated in 3 ways according to formulas (8), (9), (10):

a) when solving the equation system:

b) when directly applying the formulas:

$=\quad ;$

c) when calculating with "Microsoft Excel" spreadsheet (Shurong etc., 2014). Statistical functions are used - CORREL, SLOPE, INTERCEPT, RSQ.

In the article, parameters are calculated by applying the statistical functions of Microsoft Excel spreadsheet.

It is estimated that wage is the main motivating factor for employees and, when prices of personal consumption goods and services rise, employees usually expect for their wage to grow according to the increase in the price level (Žiogelytè, 2011). When using comparative statistical analysis in determining the annual AW increase by 8.7 percent in the Baltic States during 2004-2013, it is important to evaluate how it affects the main statistical income indicators of business economy and the Baltic States - Gross domestic product and added value. In the analysis, the inter-variables are marked as follows: value reflecting the general income of people which is selected by a factorial (independent) variable - average monthly gross wages (EUR) in Estonia, Latvia and Lithuania, while economic and business 
income indicators of the Baltic States which are selected by resulting (dependent) variables: Gross domestic product (GDP) per month and the business generated added value (AV) per month. Regression coefficient can be calculated when calculating the linear correlation coefficient. It may vary in the interval $(-1 ; 1)$. The closer the regression coefficient is to 1 or 1 , the stronger the relation. When regression coefficient has a negative value, the relation is reversed between the analysed variables (Valkauskas, 2005, Pabedinskaite, 2005).

Correlations of the average wage with GDP and AV show that, although the Lithuanian values of GDP and AV are significantly higher than in Estonia and Latvia (GDP 1.9 and AV 1.5 times), however, the value of the average wage in Lithuania is lower than in Estonia (by 1.4 times) and in Latvia (by 1.1 times). It means that those working in Lithuania earn less when creating GDP and generating AV, than those working in Estonia and Latvia.

In Figures 4 and 5, the inter-variable result points of statistical indicators are marked with triangle points while the variable unit concentration by the straight line is marked with a solid line. When analysing correlations, a relation was additionally assessed according to the "Gold Standard" effect to the value of assessed income. In the Figures, the variable result points to such effect are marked with square points while the variable concentration by the straight line is marked with a dotted line.

While business company employers pay wages to their employees from the gained added value, it is important to assess the extent to which wage changes affect the added value.

When assessing the effect of changes in the average monthly wage (AW) in the Baltic States to the added value, it was found that the relation between these two variables is direct and very strong, because the linear correlation values $(r=0.94)$ fall within the $0.91-1.00$ interval. Based on the analytical aspects of regression equation between GDP and the added values, it can be stated that GDP increased by 1 EUR also accordingly increases the added value in Estonia, Latvia and Lithuania by 1.22; 1.91 and 3.34 EUR. Paradoxically, Lithuania has the lowest AW value, but its increase increases the added value to a greater extent than in Estonia and Latvia. Furthermore, part of the created AV is used for paying wages to employees, for various state taxes and employment maintenance. The resulting elasticity coefficient shows that AW increased by 1 percent also accordingly increases the added value in Estonia, Latvia and Lithuania by $0.81 ; 0.78$ and 0.85 percent. The correlation index $\left(R^{2}=0.87-0.89\right)$ shows that the relation between the AW and the added value is strong. The calculated determination coefficient $\left(D_{x}\right)$ shows that changes in AW mostly affect the added value by 47 percent to employees in Lithuania, 40 in Latvia and 39 in Estonia.

Figure 4 shows the correlation after assessing the "Gold Standard" (marked as y(A) in the equation, in the Figure) effect. In both cases, it is possible to see the direct dependence of the AW and the added value while the unit of points corresponding to the analysed results is concentrated according to the straight line. It can be stated that direct AW increase, mostly in Lithuania, increases the added value according to absolute values and when assessing the "Gold Standard" effect.

When people receive income, they have the opportunity to buy certain goods and services, thereby contributing to the gross domestic product (hereinafter referred to as GDP). 
During the analysis, it was found that the relation between these two variables in the Baltic States is direct and very strong because the linear correlation value $(r=0.94)$ is equal to 94 percent. The relation of these variables is presented in Figure 5.

Figure 4: The correlative field of the average monthly wage and added value per month with a straight regression line
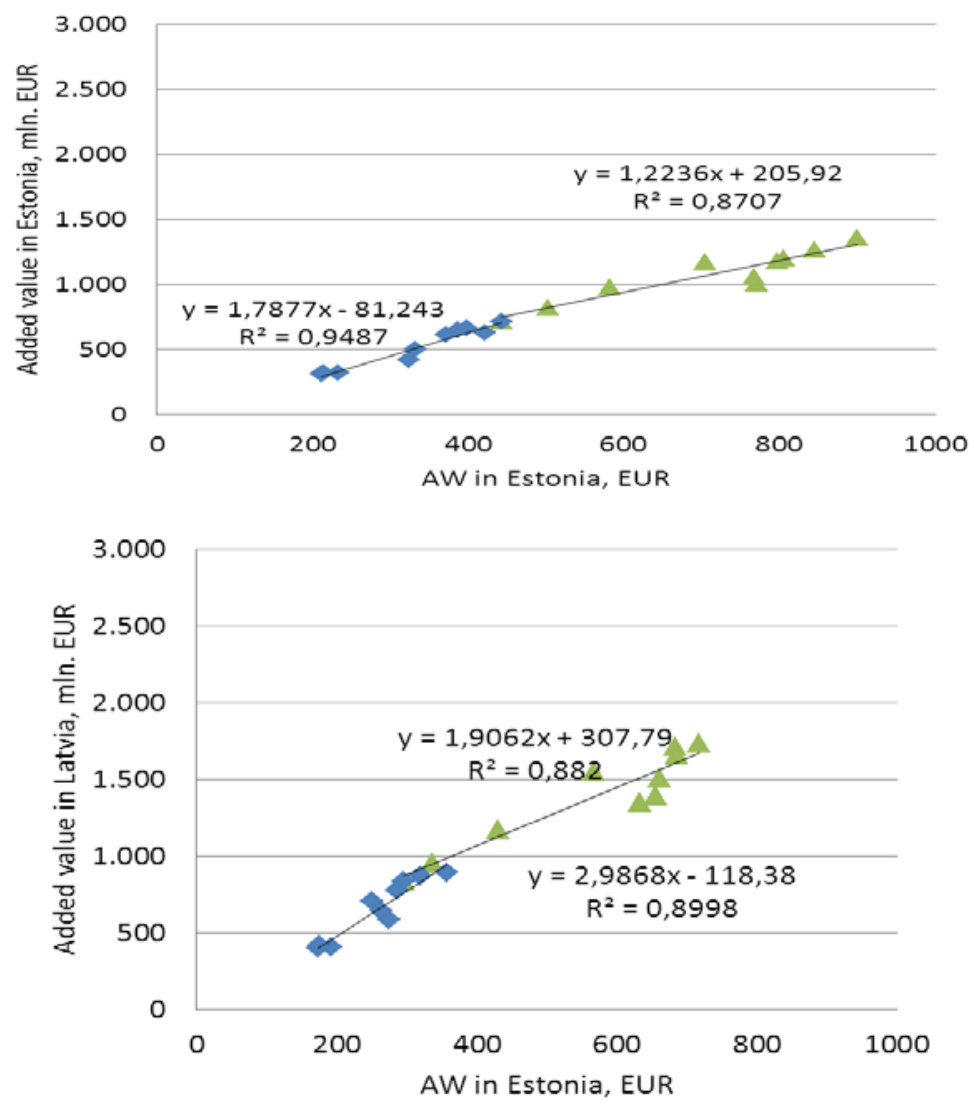


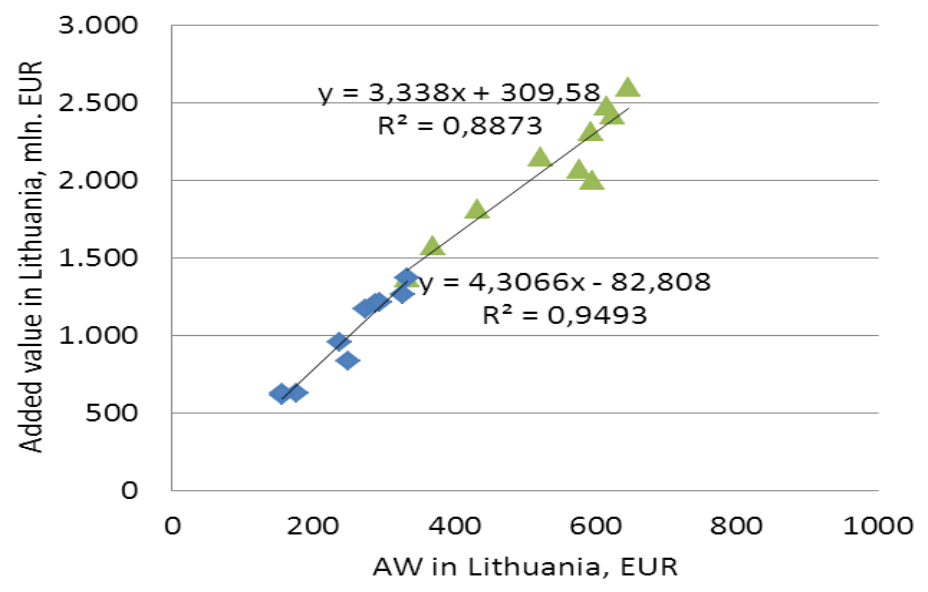

Source: Eurostat and The London Bullion Market Association data (Author's calculations)

Figure 5 shows the direct dependence of AW and GDP while the unit of points, which match the analysed results in the Baltic States, is concentrated alongside the straight line. The analytical aspects of regression equation between AW and GDP in the Baltic States show that an increase of AW by 1 EUR also accordingly increases GDP in Estonia, Latvia and Lithuania by 1.42; $2.1 ; 3.74$ EUR.

When AW increases in the Baltic States by 1 percent, the GDP also increases accordingly in Estonia, Latvia and Lithuania by $0.82 ; 0.76$ and 0.86 percent which is shown by the elasticity coefficient. The correlation index $\left(R^{2}=0.86-0.89\right)$ shows a strong relation between AW and GDP in the Baltic States. The determination coefficient $\left(D_{x}\right)$ shows that AW variations in Estonia, Latvia and Lithuania determine the GDP accordingly by 42; 33 and 47 percent.

Figure 5 shows the correlation after assessing the "Gold Standard" (presented as y(A) in the equation, in the Figure) effect. In both cases, it is possible to see the direct dependence of AW and GDP while the unit of points corresponding to the analysed results is concentrated according to the straight line. Direct AW increase, mostly in Lithuania, increases the GDP according to the absolute values and when assessing the "Gold Standard" effect.

Figure 5: The correlative field of the average monthly wage and gross domestic product per month with a straight regression line 
Purchasing Power and Value of the Average Wage in the Baltic States
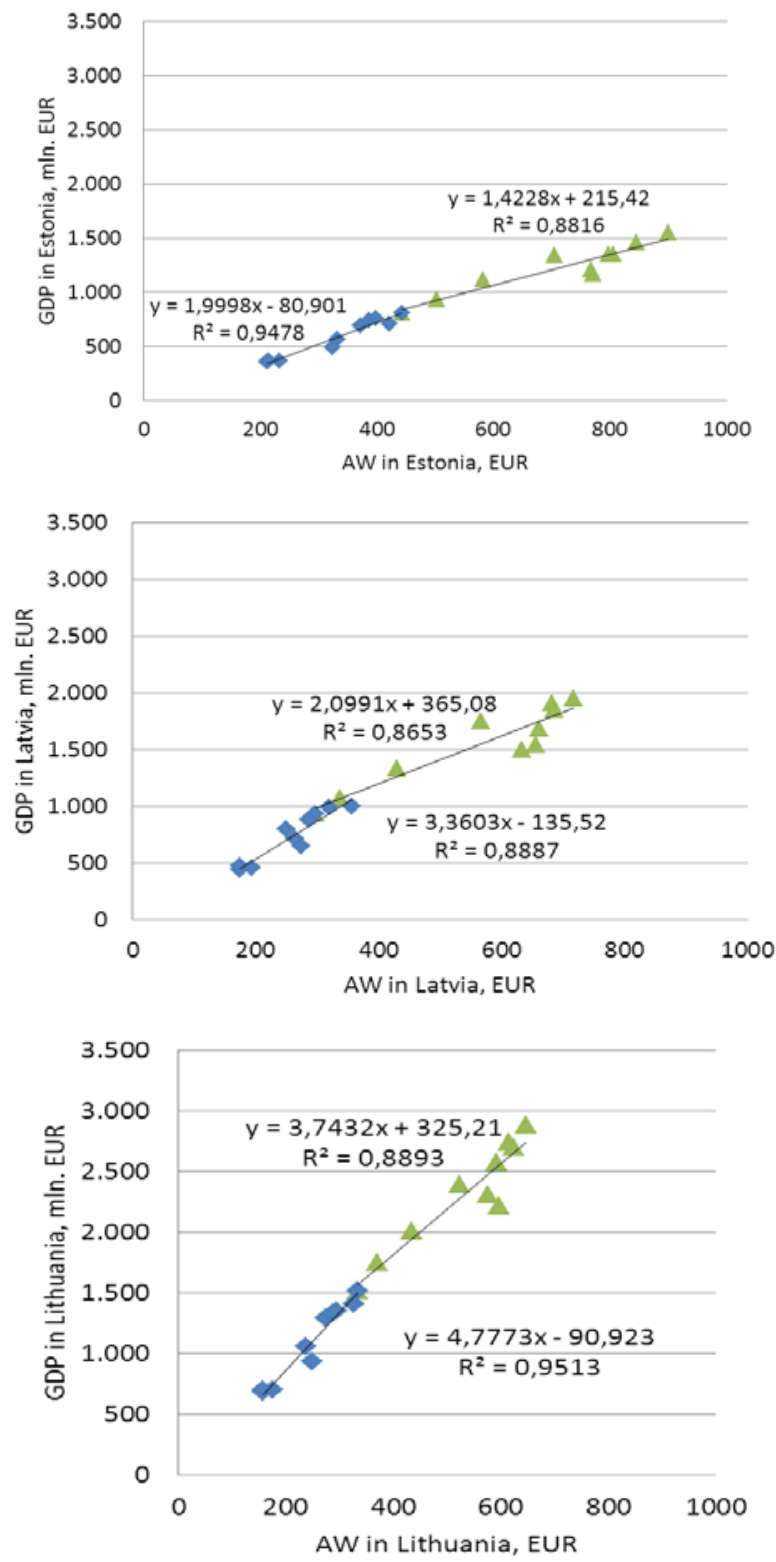

Source: Eurostat and The London Bullion Market Association data (Author's calculations) Conclusions 
Although in absolute values, AW increased in the Baltic States every year on an average of 8.7 percent, however, when assessing the true value of AW (in relation to gold) - it decreased each year by 2.7 percent. The continuous increase in prices of almost all goods and services in Estonia, Latvia and Lithuania points out the decrease of the purchasing power of Euro in the Baltic States.

During the research, when calculating according to the "Gold Standard" principle (according to the changes in the price of gold), it was discovered that the material value of Euro from 2004 to 2013 has declined by 2.9 times. The reason for this phenomenon is the excess emission of Euros, as not having the payment means of specific material value, which caused the inflation of this currency.

Calculations have shown that the purchasing power of Litas in Lithuania, assessed according to the multiplicative standard inflation coefficient, during the same period of time has only decreased by 1.4 times. It is two times less than the fall in the true value of Euro. The reason for this phenomenon can be based on a hypothesis that most subjects in the Baltic country market lack knowledge and are not aware of the decline rate of their received income value, which was revealed by this research. An illusory belief that modern money has a constant or a very slowly changing value is becoming a stronger reason for the loss of their assets or capital.

An analysis of changes in the true value of the average monthly wage in the Baltic States has shown that, during 2004-2013, the value decreased minus 63 percent while its purchasing power - minus 45 percent. It clearly shows that the country's employees actually became poorer.

Although the Lithuanian values of GDP and AV are significantly higher than in Estonia and Latvia (GDP 1.9 and AV 1.5 times), however, the value of the average wage in Lithuania is lower than in Estonia (by 1.4 times) and in Latvia (by 1.1 times).

This correlation regression analysis has shown that an increase in AW (especially in Lithuania) directly raises the country's economic efficiency by increasing the country's added value and GDP according to the absolute values and when assessing the "Gold Standard" effect.

\section{References}

1. Baležentis, A., Baležentis, T., Misiūnas, A. (2011). Darbo užmokesčio pokyčiai Lietuvos žemės ūkio sektoriuje ekonominio nuosmukio laikotarpiu. Management theory and studies for rural business and infrastructure development, 3(27): 14-22.

2. Bank of Lithuania. (2014). Lietuvos bankas: Užsienio valiutų santykių statistika. Retrieved August 26, 2014, from http://lb.lt/uzsienio_valiutu_santykiu_statistika

3. Bartosevičienė V. (2007). Ekonominè statistika (28-52). Kaunas: Technologija.

4. Čekanavičius, V., Murauskas, G. (2002). Statistika ir jos taikymai, II dalis (106133). Vilnius: TEV. 
5. Gardner, R, C., Neufeld, W., J. (2013). What the Correlation Coefficient Really Tells Us. Canadian Journal of Behavioural Science / Revue canadienne des sciences du comportement, 45(4): 313-319.

6. Gerikienè, V., Blažienè, I. (2009). Valstybinio sektoriaus darbuotojų darbo apmokèjimo reguliavimas Lietuvoje. Jurisprudence: Research Papers. Vilnius: Mykolo Romerio Universiteto Leidybos centras, 4(118): 299-320.

7. Gražytė - Molienè, O. (2004). Statistika: I dalis (38-67). Vilnius: Vilniaus verslo kolegija.

8. Gronskas V. (2007). Ekonomine analize (148-162). Kaunas: Technologija.

9. Gruževskis, B., Orlova, U., L. (2012). Sąvokos „Gyvenimo kokybe““ raidos tendencijos. Social work. Mykolas Romeris university, 11(1): 7-18.

10. Jasinavičius, R. (2012). Investavimo iliuzijos. Investuok: žurnalas norintiems investuoti. Kaunas: Leidybos studija, 4(51): 18-20.

11. Jasinavičius, R., Ganiprauskas, V. (2011). Namų ūkių skolinimo ir valdžios skolinimosi priemoniu itaka Lietuvos ekonominei gerovei. Whither our economies: 1'st International scientific conference: conference proceedings. Mykolas Romeris university: 182-189.

12. Jasinavičius, R., Ganiprauskas, V. (2012). Lietuvos pagrindinių pajamų ir socialinių išmokų vertès kitimo tyrimas. Practice and research in private and public sector 2012: conference proceedings: international scientific conference, April 26 - 27. Mykolas Romeris university: 417-430.

13. Laidmäe, V., Hansson, L., Leppik, P., Tulva, T., Lausvee, E. (2012). Later Life In Estonia: Satisfaction With Life And Intergenerational Support. The Internet Journal of Geriatrics and Gerontology, Vol. 6, No. 1. Retrieved September 21, 2014, from http://ispub.com/IJGG/6/1/4401\#

14. Lithuanian Department of Statistics. (2014). Kas tai yra vartojimo prekių ir paslaugų statistinis krepšelis ir jo sudètis? Retrieved September 14, 2014, from http://www.stat.gov.lt/lt/faq/view/?id=2120\&page $=0$

15. Mačernytè-Panomariovienè, I. (2003). Apmokẻjimas už darba ir jo užtikrinimas. Vilnius: LTU Leidybos centras.

16. Pabedinskaite, A. (2005). Kiekybiniai sprendimu metodai: Koreliaciné regresine analize. Prognozavimas. I dalis (6-55). Vilnius: Technika.

17. Paužinskaitè, E. (2012). Gyventojų darbo užmokesčio apmokestinimo Baltijos šalyse ypatumai. I'st international scientific conference „problems of tax policy“: 100-105.

18. Raškinis, D. (2005). Minimalaus darbo užmokesčio padidinimo ịtakos smulkiajam ir vidutiniam verslui analize: Mokslinio tyrimo darbas. UAB "ETKC"

19. Statistical office of the European Union (Eurostat). (2014). Statistika (Duomenu bazès). $\quad$ Retrieved September 2, 2014, from http://epp.eurostat.ec.europa.eu/portal/page/portal/statistics/themes 
20. Shurong, Zh., Dandan, J., Zhidong, B., Xuming, H. (2014). Inference on multiple correlation coefficients with moderately high dimensional data. Biometrica. 101(3): 748-754.

21. Tanning, L, Tanning, T. (2012). Labour Costs and Productivity Analysis of EastEuropean Countries. International Journal of Business and Social Science, Vol. 3 No. 20. $\begin{array}{llll}\text { Retrieved } \quad \text { September } & \text { 21, from }\end{array}$ http://www.ijbssnet.com/journals/Vol_3_No_20_Special_Issue_October_2012/9.pdf

22. Tanning, L, Tanning, T. (2013). An Analysis Of Eastern European And Baltic Countries Wages. International Journal of Arts and Commerce. Vol. 2, No. 3. Retrieved September 19, 2014, from http://www.ijac.org.uk/images/frontImages/gallery/Vol._2_No._3/13.pdf

23. Tanning, L, Tanning, T. (2013). Estonian, Latvian, and Lithuanian Companies’ Working Efficiency before and after the Economic Crisis. International Journal of Business and Social Science. Vol. 4, No. 6. Retrieved September 19, 2014, from http://www.ijbssnet.com/journals/Vol_4_No_6_June_2013/16.pdf

24. The London Bullion Market Association (2014). The Price of Gold, Retrieved August 29, 2014, http://www.lbma.org.uk/pricing-and-statistics

25. Varanauskienė, J. (2012). Šalies ekonominès problemos kerta kiekvienam, bet nevienodai. $\quad$ Retrieved September 2, 2014, from http://www.delfi.lt/news/ringas/lit/jvaranauskiene-salies-ekonomines-problemos-kertakiekvienam-bet-nevienodai.d?id=59266385

26. Weixin, Y., Longhai, L. (2014). A New Regression Model: Modal Linear Regression. Scandinavian Journal of Statistics. 41(3): 656-671.

27. Žiogelytè, L. (2011). Darbo apmokèjimui įtaką darančių vidinių ir išorinių veiksnių vertinimas. Contemporary issues in business, management and education 2011, Vilnius Gediminas Technical University Press Technika: 313-325.

28. Žiogelytė, L. (2010). Darbo užmokesčio pokyčio vertinimas Lietuvos darbo rinkoje. Science - future of Lithuania, Vilnius Gediminas Technical University Press Technika, Vol.2, No.2: 119-125.

29. Žukauskas, V. (2008). Imonių pelnas ir darbo užmokestis: mitai ir realybè. Retrieved August 31, 2014, from http://www.lrinka.lt/index.php?act=main\&item_id=4932

30. Žukauskas, V. (2011). Brangsta prekès? Pinga pinigai! Retrieved September 13, 2014 from http://www.lrinka.lt/index.php?act=main\&item_id=6154 


\section{About the Authors:}

Rimvydas JASINAVIČIUS, Assoc. Prof. Dr. Institute of Economics and Business, Faculty of Economics and Finance Management, Mykolas Romeris University, Lithuania.

Research fields: economics, business, investment, management of personal finance, Theory of Constraints (TOC).

Vidmantas GANIPRAUSKAS, Lector, Institute of Economics and Business, Faculty of Economics and Finance Management, Mykolas Romeris University, Lithuania.

Research fields: economics, business, investment, management of personal finance, Theory of Constraints (TOC). 